\title{
Pathogenicity of Entomophatogenic Fungi Lecanicillium Lecanii Against Predator Insect Menochilus Sexmaculatus
}

\author{
DOI: $10.18196 /$ pt.2020.115.63-68
}

\author{
Mochammad Syamsul Hadi ${ }^{1}$, Achmad Fitriadi Taufiqurrahman ${ }^{1}$, Fery Abdul Choliq ${ }^{1}$, \\ Istiqomah $^{2}$, Sri Karindah ${ }^{1}$ \\ ${ }^{1}$ Department of Plant Pest and Disease, Faculty of Agriculture, University of Brawijaya, \\ $J l$. Veteran, Malang, East Java, Indonesia \\ ${ }^{2}$ Department of Agrotechnology, Faculty of Agriculture, Darul 'Ulum Islamic University, \\ Jl. Airlangga 3, Sukodadi, Lamongan, East Java, Indonesia \\ *Corresponding author, email: mshadi.fpub@gmail.com
}

\begin{abstract}
Lecanicillium lecanii is an insect pathogenic fungus that is often used for pest control and has a wide range of hosts. The L. lecanii is capable of infecting several types of host insects including the Order Orthoptera, Hemiptera, Lepidoptera, Thysanoptera and Coleoptera. The extent of this fungus host range was feared to have a negative effect on predator insects Menochilus sexmaculatus. This study aims were to determined the pathogenicity of the fungus $L$. lecanii against the imago predatory beetle M. sexmaculatus, to know how the predation ability and the number of eggs fecundity of Imago M. sexmaculatus after application L. lecanii. The research was arranged in Randomized Block Design with 4 replications. The conidia density of L. lecanii used were 105, $10^{7}, 10^{8}, 109$ conidia/ml, $1 \mathrm{ml} /$ I of Iufenuron insecticide as positive control and sterile distilled water as negative control. The research showed that the mortality percentage of M. sexmaculatus due to L. lecanii application is low and medium. The L. lecanii was not affected for preying ability on imago M. sexmaculatus but gave effect to the number of eggs fecundity of imago M. sexmaculatus.
\end{abstract}

Keywords: Predator beetle, Biological control, Entomopathogenic Fungus, Lecanicillium

\begin{abstract}
ABSTRAK
Lecanicillium lecanii adalah jamur patogen serangga yang sering digunakan untuk pengendalian hama dan memiliki kisaran inang yang luas. L. lecanii dapat menginfeksi beberapa jenis inang dari golongan serangga diantaranya ordo Orthoptera, Hemiptera, Lepidoptera, Thysanoptera, dan Coleoptera. Luasnya kisaran inang jamur ini dikhawatirkan memiliki efek negatif pada serangga predator Menochilus sexmaculatus. Penelitian ini bertujuan untuk mengetahui patogenesitas jamur L. lecanii terhadap imago kumbang predator M. sexmaculatus, mengetahui kemampuan predasi dan jumlah fekunditas telur imago M. sexmaculatus setelah aplikasi L. lecanii. Penelitian menggunakan rancangan acak kelompok (RAK) dengan 4 ulangan. Kerapatan kondia L. lecanii yang digunakan adalah 106, 107, 108, $10^{9}$ konidia/ml, $1 \mathrm{ml} / 1$ insektisida lufenuron sebagai kontrol positif, dan air suling steril sebagai kontrol negatif. Hasil menunjukkan bahwa presentase kematian M. sexmaculatus akibat aplikasi L. lecanii adalah rendah dan sedang. Aplikasi L. lecanii tidak mempengaruhi kemampuan M. sexmaculatus dalam memangsa, tetapi berpengaruh terhadap jumlah fekunditas telur imago M. sexmaculatus.
\end{abstract}

Kata Kunci: Kumbang predator, Pengendalian hayati, Jamur entomopatogenik, Lecanicillium

\section{INTRODUCTION}

The use of entomopathogens for insect pest control is now widely introduced to farmers through various programs. It aims to replace synthetic insecticides that are harmful to the environment. One of the most commonly used entomopathogens is Lecanicillium lecanii (Zimmerman) which have wide host range (Shinde et al., 2010). L. lecanii produces secondary metabolite compounds that are toxic to insects. The secondary metabolite compounds consist of hydrolytic enzymes such as proteases, chitinases and lipases (Hasan, et al., 2013) and toxin compounds such as dipicolinic acid (Claydon and Grove, 1982), vertilecanin-A1, decenedioic acid and 10-hydroxy-8-decenoic acid (Soman et al., 2001). The L. lecanii is capable of infecting several insects orders including Orthoptera, Hemiptera, Lepidoptera, Thysanoptera and Coleoptera (Khoiroh, Isnawati, \& Faizah, 2014).

The use of L. lecanii as a biological control in agroecosystems should be considered to influence beneficial organisms such as predators. The wide range of hosts from this entomopathogen is feared to infect predatory insects. One of the predatory insects potentially infected by Lecanicillium lecanii 
is Menochillus sexmaculatus. M. sexmaculatus is one of a kind polyphagous predatory beetle against several insect pests including Acyrthosiphon pisum (Harris), Aphis craccivora (Koch.), Aphis fabae (Theobald), Aphis gossypii (Glover), Aphis ruborum (Bor), Myzus persicae (Sulz), Rhopalosiphum maidis (Fitch), Dialeurodes citri (Ash), Diaphorina citri (Kuw.), and Tetranychus orientalis (Mcg) (Irshad, 2001). The wide range of prey of $\mathrm{M}$. sexmaculatus makes these predatory beetle found in various agroecosystems of both food crops and horticultural crops (Riyanto et al., 2011).

Wang et al. (2005) reported that the crude toxins have low toxicity against beetle larva of Delphastus catalinae (with $\mathrm{LC}_{50}$ values of 1942 (1393-2710) and 2471 (1291-4731) p.p.m., respectively (approximately 10- and 12-fold of field rate of application 200 p.p.m.). The adult beetles had less sensitivity to crude toxins with $\mathrm{LC}_{50}$ values of 4260 (3376-5375) and 4426 (1734-11298) p.p.m., respectively (approximately 20-and 22-fold of field rate 200 p.p.m.). The consumption and foraging capacity was significantly impaired especially in the second-instar larval beetles which took longer time (more than twice of the control beetles) to consume whitefly eggs after $D$. catalinae exposure to toxins. The study about the impact of L. lecanii application on predatory beetle M. sexmaculatus has not been widely reported, so further research is needed on the side effects of L. lecanii application on $M$. sexmaculatus. The benefit from this research is the information about the impact of application of $L$. lecanii on mortality of adult M. sexmaculatus. The preying ability of M. sexmaculatus and fecundity of adult M. sexmaculatus after application of L. lecanii.

\section{MATERIALS AND METHODS}

Places and Time

The research was conducted from February to October 2016 at the Pest Laboratory and Biologi- cal Control Laboratory of Plant Pest and Disease Department, Faculty of Agriculture, University of Brawijaya.

\section{Research Preparation}

Preparation of research is the collection and propagation of predatory beetles $M$. sexmaculatus taken directly from the field of rice crops, corn, beans, and chili. M. sexmaculatus obtained was maintained using a cage and fed Aphis sp.

Propagation of $L$. lecanii are done on two mediums, solid medium (PDA) and liquid medium (DPE). Propagation of L. lecanii on liquid medium using a shaker orbital with 120 Rpm for 48 hours. Isolate L. lecanii obtained from the collection of insect pathogens Department of Plant Pests and Diseases, Faculty of Agriculture, University of Brawijaya.

\section{Implementation of Research}

The pathogenicity test of L. lecanii on M. sexmaculatus using Randomized Block Design (RBD) 6 treatment with 4 replications. Each treatment there was 5 adults of M. sexmaculatus consisting of 2 males and 3 females. A total of 120 adults $M$. sexmaculatus were sprayed by $L$. lecanii suspension with concentration $10^{6}, 10^{7}, 10^{8}, 10^{9}$ conidia/ $\mathrm{ml}$, sterile Aquades (negative control) and IGR pesticide with lufenuron as the active ingredient (positive control).

\section{Variable Observations}

The Mortality of adult M. sexmaculatus applied by L. lecanii

The observations were made by counting the number of M. sexmaculatus died until 7 days after application of L. lecanii.

The preying ability of adult M. sexmaculatus

The preying ability of $M$. sexmaculatus was observed by counting the number of prey (Aphis sp) 
consumed by M. sexmaculatus after application of $L$. lecanii. The amount of Aphis sp used as the feed was 20. Observations start 1 day after application and were made daily for 7 days after application. The percentage of imago mortality rate was calculated using the formula:

$$
P=\frac{x}{y} \times 100 \%
$$

$\mathrm{P}$ is the percentage of the mortality, $\mathrm{x}$ is imago die, $y$ is the total number of imago observed. If in the control of mortality occurs greater than $0 \%$ and 20\% less than the treatment then mortality corrected by the formula (Abbot, 1987) :

$$
\mathrm{P}=\frac{\mathrm{p}^{\prime}-\mathrm{c}}{100-\mathrm{c}} \times 100 \%
$$

$\mathrm{P}$ is the percentage of corrected mortality rate, $\mathrm{p}$ 'the observed mortality rate on each treatment, and $\mathrm{c}$ is the mortality rate in the control.

\section{Fecundity of adult M. sexmaculatus}

Fecundity of M. sexmaculatus females was observed in insects that did not die in each treatment, observations were made by mating male and female of adult M. sexmaculatus. after the copulation occurs, the number of eggs produced first then counted.

\section{Data Analysis}

The observed data were analyzed using $F$ test at $5 \%$ level. If the response of the treatment significantly different, then proceed with BNT test at 5\% error level. Concentration and time of death of $\mathrm{M}$. sexmaculatus imago were analyzed using probit software analysis (Chi, 1997) to calculate median lethal concentration $\left(\mathrm{LC}_{50}\right)$ and median lethal time $\left(\mathrm{LT}_{50}\right)$.

\section{RESULTS AND DISCUSSION}

Patogenicity of $L$. lecanii on adult $M$. sexmaculatus Mortality

The adult of M. sexmaculatus infected by L. lecanii showed symptoms of reduced activity before death. Symptoms that appear after death are the growth of white mycelium on the body of M. sexmaculatus incubated for 2 days after death (Figure 1). According to (Barson, 1976) thats reported Scolytus scolytus (Coleoptera: Curculionidae) infected by L. lecanii softened shortly before death, and changed color from white to pale or yellow cream very pale. The death larvae are covered in white mycelium.

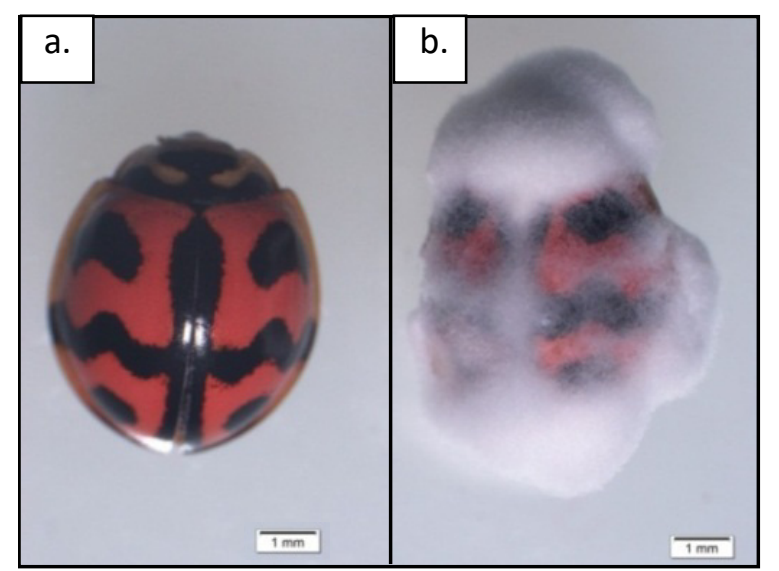

Figure 1. (a) Healthy M. sexmaculatus (b) Infected M. sexmaculatus by L. lecanii

The application of $L$. lecanii with various conidia density did not significantly affect the mortality of M. sexmaculatus (Table 1). The L. lecanii application was capable of infecting and causing death on adult of M. sexmaculatus. However, the mortality of M. sexmaculatus based on the classification by (Thungrabeab, Blaeser, \& Sengonca, 2006) pathogenicity of entomopathogenic fungi was low and medium, ranging from 15 to $38.75 \%$.

The death of M. sexmaculatus suspected due to the influence of secondary metabolite compounds produced by L. lecanii. (Claydon and Grove, 1982) and (Soman et al., 2001), states that L. lecanii produces secondary metabolite compounds, namely dipicolonic acid, vertilecanin-A1, decenedioic acid and 10-hydroxy-8-decenoic acid which can cause death in some insect pests. 
Table 1. Average Mortality of M. sexmaculatus 7 days after Application of L. lecanii

\begin{tabular}{lcc}
\hline \multicolumn{1}{c}{ Treatments } & Average mortality of $M$. sexmaculatus (\%) \pm SE & N \\
\hline L. lecanii $10^{6}$ conidia/ml & $15,00 \pm 15,00$ & 20 \\
L. lecanii $10^{7}$ conidia/ml & $10,00 \pm 05,77$ & 20 \\
L. lecanii $10^{8}$ conidia/ml & $22,50 \pm 10,31$ & 20 \\
L. lecanii $10^{9}$ conidia/ml & $38,75 \pm 22,40$ & 20 \\
Positive control (lufenuron $1 \mathrm{ml} / \mathrm{l})$ & $25,00 \pm 15,00$ & 20 \\
\hline
\end{tabular}

Notes: the data corrected by $\mathrm{P}=\frac{\mathrm{p}^{\prime}-\mathrm{c}}{100-\mathrm{c}} \times 100 \%$

the data transformed by $\sqrt{ } X+0.5$

$n=$ total insects observed

Table 2. Median Lethal Time $\left(\mathrm{LT}_{50}\right)$ L. lecanii on Adult M. sexmaculatus with Various Density Level of Conidia

\begin{tabular}{ccc}
\hline Density level (conidia/ml) & Regretion & $\mathbf{L T}_{50}$ value (Days after application) \\
\hline $10^{6}$ & $\mathrm{y}=2,19+0,79 x$ & 150,41 \\
$10^{7}$ & $\mathrm{y}=-0,67+2,08 \mathrm{x}, 32$ \\
$10^{8}$ & $\mathrm{y}=-1,29+2,54 \mathrm{x}$ & 12,43 \\
$10^{9}$ & $\mathrm{y}=0,99+1,62 \mathrm{x}$ & 12,32 \\
Positive control (lufenuron $1 \mathrm{ml} / \mathrm{l})$ & $25,00 \pm 15,00$ & 20 \\
\hline
\end{tabular}

Notes: Observation conducted until 7 days.

The $\mathrm{LC}_{50}$ value of the $L$. lecanii on adult $\mathrm{M}$. sexmaculatus mortality was $7.58 \times 10^{9}$ conidia/ml. This value indicates that the $L$. lecanii can infect and cause death on adult M. sexmaculatus by $50 \%$ at the conidia density level of $7.58 \times 10^{9}$ conidia/ $\mathrm{ml}$. Based on these results, the application of $L$. lecanii does not endanger the population of $\mathrm{M}$. sexmaculatus. In general, the density of the L. lecanii used by farmers in Indonesia to control insect pests is below $10^{8}$ conidia/ $\mathrm{ml}$. However, the application of the L. lecanii is advised not to be done too often because of the potential to increase mortality in beneficial insects (Prayogo \& Suharsono, 2005).

The higher density of conidia L. lecanii applied to adult $M$. sexmaculatus the more rapidly causing the death of adult M. sexmaculatus. The density of L. lecanii with fastest $\mathrm{LT}_{50}$ is at $1 \times 10^{9}$ conidia/ $\mathrm{ml}$ of 12.32 days after application. High conidial concentration affects the speed of penetration on the walls of the insect body to speed up the infection process. (Masyitah et al., 2017) states that insect pathogenic fungi with a greater number of conidia will provide a faster epizootic response to targeted insects.

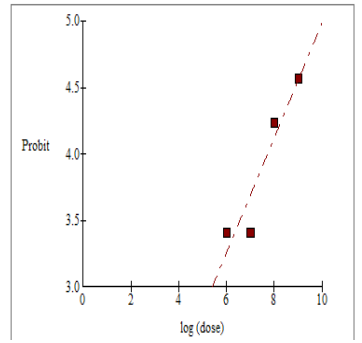

Figure 2. LC $_{50}$ graphic L. lecanii on M. sexmaculatus Beetle
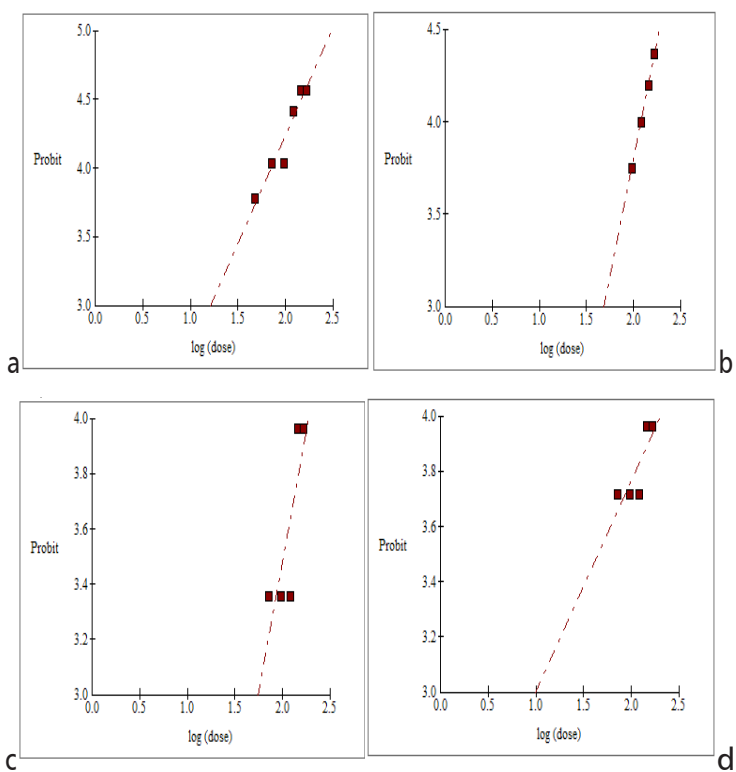

Figure 3. Lethal time graphic of $L$. lecanii with differents concentration on M. sexmaculatus Beetle (a) $\mathrm{LT}_{50}$ graphic at $10^{9}$ conidia $/ \mathrm{ml}$, (b) $\mathrm{LT}_{50}$ graphic at $10^{8}$ conidia $/ \mathrm{ml}$, (c) $\mathrm{LT}_{50}$ graphic at $10^{7}$ conidia/ml, (d) $\mathrm{LT}_{50}$ graphic at $10^{6}$ conidia/ml 
Table 3. Averages Number of $A$. gossypii that were Preyed by Adult M. sexmaculatus until 7 Days After Application

\begin{tabular}{lcc}
\hline \multicolumn{1}{c}{ Treatments } & Means Aphids sp per day \pm SE & $\mathrm{N}$ \\
\hline L. lecanii $10^{6}$ conidia/ml & $11,67 \pm 1,04$ & 17 \\
L. lecanii $10^{7}$ conidia/ml & $11,58 \pm 0,75$ & 17 \\
L. lecanii $10^{8}$ conidia/ml & $12,13 \pm 0,89$ & 14 \\
L. lecanii $10^{9}$ conidia/ml & $10,49 \pm 0,53$ & 12 \\
Positive control (lufenuron 1 ml/l) & $11,26 \pm 0,75$ & 15 \\
Negative control (Sterill Destilated Water) & $11,20 \pm 0,97$ & 18 \\
\hline
\end{tabular}

Notes: $\mathrm{n}=$ total insects observed.

Table 4. Averages Number of $A$. gossypii that were Preyed by Adult M. sexmaculatus until 7 Days After Application

\begin{tabular}{lcc}
\hline \multicolumn{1}{c}{ Treatments } & Average Number of Eggs + SE & $\mathrm{N}$ \\
\hline L. lecanii $10^{6}$ conidia/ml & $4,25 \pm 1,44 \mathrm{ab}$ & 10 \\
L. lecanii $10^{7}$ conidia/ml & $2,00 \pm 1,15 \mathrm{a}$ & 11 \\
L. lecanii $10^{8}$ conidia/ml & $2,00 \pm 1,15 \mathrm{a}$ & 10 \\
L. lecanii $10^{9}$ conidia/ml & $1,00 \pm 0,58 \mathrm{a}$ & 7 \\
Positive control (lufenuron 1 ml/l) & $1,00 \pm 0,58 \mathrm{a}$ & 9 \\
Negative control (Sterill Destilated Water) & $5,25 \pm 1,89 \mathrm{~b}$ & 9 \\
\hline
\end{tabular}

Notes: The number followed by the same letter is not significantly different at the $5 \%$ level of the LSD test.

Preying Ability of M. sexmaculatus

The application of L. lecanii did not have a significant effect on the prey ability of $M$. sexmaculatus. The ability to prey on M. sexmaculatus remains high despite the application of the L. lecanii, this can be seen from the number of Aphis sp. which were preyed on by adult M. sexmaculatus showed no difference when compared to controls (Table 3).

\section{Fecundity of adult M. sexmaculatus}

The application of L. lecanii affect on fecundity of adult M. sexmaculatus. The higher density level of the L. lecanii applied, the number of eggs placed by the female M. sexmaculatus decreases. The decrease in the number of eggs placed by M. sexmaculatus females reached $80.96 \%$ compared with controls. Thats indicates that the application of fungus $L$. lecanii affects the fecundity of M. sexmaculatus. (Wang, Huang, You, Guan, \& Liu, 2005) also reported that the application of the L. lecanii was able to decrease fecundity of the predatory beetle D. catalinae (Coleoptera: Coccinellidae).

The decrease number of eggs produced by $M$. sexmaculatus due to the application of L. lecanii allegedly because M. sexmaculatus lost nutrients in the body that support the process of egg formation. According to (Tanada \& Kaya, 1993), after the fungus of the entomopathogen successfully penetrated the cuticle, the hyphae in the insect body will develop and multiply by absorbing the nutrients present in the insect's body. Besides, each insect has a different strategy in dealing with nutritional deficiencies. Especially for the Coccinellidae family the efforts undertaken in the face of nutritional deficiency is to reduce the amount of egg production (Hodek, van Emden, \& Honek, 1996).

\section{CONCLUSION}

The application of $L$. lecanii at density level $10^{6}$, $10^{7}, 10^{8}, 10^{9}$ conidia/ml capable to infecting and causing death on adult of M. sexmaculatus with mortality value $15,00,10,00,22,50$, and 38,75\% respectively. The application of $L$. lecanii did not have effect on the prey ability of M. sexmaculatus. The application of L. lecanii is capable to decrease fecundity of adult M. sexmaculatus. 


\section{REFERENCES}

Abbot, W. (1987). A Method of Computing The Effectivenes of An Insecticide. Journal of American Mosquito control Assition, 302-307.

Barson, G. (1976). Laboratory Studies on the fungus Verticillium lecanii, a larval pathogen of he large elm bark beetle (Scolytus scolytus). Annals of Applied Biology, 207-214.

Chi, H. (1997). Probit Anlysis. Taiwan: National Chun Hsing University.

Claydon, N., \& Grove, J. F. (1982). Insecticidal secondary products from the entomogenous fungus Verticillium lecanii. Journal of Invertebrate Pathology, 40: 413-418.

Hasan, S., Ahmad, A., Purwar, A., Khan, N., Kundan, R., \& Gupta, G. (2013). Production of extracellular enzymes in the entomopathogenic fungus Verticillium lecanii. Bioinformation, 238-242.

Hodek, I., van Emden, H. F., \& Honek, A. (1996). Ecology and Behaviour of the Ladybird Beetle (Coccinellidae). Netherland: Wiley-Blackwell.

Irshad, M. (2001). Distribution, Hosts, Ecology and Biotic Potentials of Coccinelids of Pakistan. Pakistan Journal of Biological Sciences, 1259-1263.

Khoiroh, F., Isnawati, \& Faizah, U. (2014). Pathogenicity of Entomopathogenic Fungus Lecanicillium lecanii as Bioinsectiside for Pest Control of Brown Plant Hopper (Nilaparvata Lugens) In Vivo. Lentera Bio, 115-121.

Masyitah, I., Sitepu, S.F., \& Safni, I. (2017). Potency of Entomopathogenic Fungi to control Oriental Leafworm Spodoptera litura F. on Tobacco In Vivo. J. Agroekoteknologi FP USU, 5(63): 484-493.

Prayogo, Y., \& Suharsono. (2005). Optimization of Soybean Pod Sucking bug (Riptortus linearis) Pest Control with Entomopathogenic Fungi Verticillium lecanii. Jurnal Litbang Pertanian, 123-130.

Riyanto, Herlinda, S., Irsan, C., \& Umayah, A. (2011). The abundance and species diversity of predatory insects and parasitoid of Aphis gossypii in South Sumatra. J. HPT Tropika 11(1): 57-68.

Shinde, S., Patel, V. K.G., Purohit, M.S., Pandya, J.R., \& Sabalpara, A.N. (2010). "Lecanicillium lecanii ( Zimm.) Zare and Games" an Important Biocontrol Agent for the Management of Insect Pests - a Review. Agric. Rev. 31(4): 235-252.

Soman, A. G., Gloer, J. B., Angawi, R. F., Wicklow, D. T., \& Dowd, P. F. (2001). Vertilecanins: New Phenopicolinic Acid Analogues from Verticillium lecanii. J. Nat. Prod., 64: 189-192.

Tanada, Y., \& Kaya, H. K. (1993). Insect Pathology. New York: Gulf Professional Publishing.

Thungrabeab, M., Blaeser, P., \& Sengonca, C. (2006). Possibilities for Biocontrol of The Onion thrips Thrips tabaci Lindeman (Thysanoptera: Thripitidae) using Difference Entomopathogenic from Thailand. Mitteilungen der Deutschen Gesellschaft für Allgemeine und Angewandte Entomologie , 299-304.

Wang, L., Huang, J., You, M., Guan, X., \& Liu, B. (2005). Effects of toxins from two strains of Verticillium lecanii (Hyphomycetes) on bioattributes of a predatory ladybeetle, Delphastus catalinae (Coleoptera: Coccinellidae). Journal of Applied Entomology, 32-38. 